\title{
The growth endocrine axis and inflammatory responses after laparoscopic cholecystectomy
}

\author{
Themistoklis Floros, ${ }^{1}$ Anastassios Philippou, ${ }^{2}$ Dimitrios Bardakostas, ${ }^{1}$ \\ Dimitrios Mantas, ${ }^{1}$ Michael Koutsilieris ${ }^{2}$ \\ ${ }^{1} 2^{\text {nd }}$ Propaedeutic Department of Surgery, Laiko General Hospital, ${ }^{2}$ Department of Experimental Physiology, Medical \\ School, National and Kapodistrian University of Athens; Athens, Greece
}

\begin{abstract}
OBJECTIVE: It is well known that conventional surgery leads to detrimental immune and catabolic responses, thus there is growing interest in the effect of minimally invasive techniques on postoperative endocrine and immune function. The aim of this prospective study was to evaluate the growth hormone (GH)/insulin-like growth factor-1 (IGF-1)/IGF binding protein-3 (IGFBP-3) axis and acute phase (interleukin-6, IL-6, and C-reactive protein, CRP) responses in patients who underwent laparoscopic cholecystectomy. DESIGN: Twenty-nine patients (16 women, 13 men; age: $58 \pm 8$ years) with a history of uncomplicated symptomatic cholelithiasis participated in the study. Blood samples were collected prior to and at $24 \mathrm{hrs}$ and $48 \mathrm{hrs}$ after laparoscopic cholecystectomy. Serum concentrations of GH, IGF-1, IGFBP-3, and IL-6 were determined by standard sandwich enzyme-linked immunosorbent assay (ELISA), while CRP was measured by nephelometry. ANOVA with repeated measures and Tukey's post-hoc test were used to evaluate changes in serum measurements. RESULTS: The laparoscopic cholecystectomy resulted in a significant postoperative increase in circulating levels of IL-6 $(p=0.031)$, which is the main cytokine responsible for inducing the acute inflammatory response, and of the acute phase protein $C R P(p=0.005)$. A significant increase in GH levels at $24 \mathrm{hrs}(\mathrm{p}=0.034)$ and decrease of IGF-1 on both postoperative days were also found $(p=0.045,0.044)$, while no changes were documented in IGFBP-3 levels. Significant correlations were revealed between postoperative levels of the acute phase proteins and growth axis hormones $(p<0.05-0.001)$. CONCLUSIONS: Our findings suggest that laparoscopic cholecystectomy induces acute phase endocrine and immune responses. These changes may represent a state of systemic inflammation and GH resistance, compatible with possible cytokine-induced anti-anabolic or catabolic effects even after this minimally invasive cholecystectomy.
\end{abstract}

Key words: Acute phase response, Growth hormone, Inflammation, Insulin-like growth factor-1, Interleukin-6, Laparoscopy 


\section{INTRODUCTION}

Over the last decade, an increasing number of studies have been conducted to investigate the effects of minimally invasive surgical techniques on surgical stress response and a variety of immune function parameters. ${ }^{1-4}$ The introduction of advanced laparoscopic methods has revealed several clinical advantages of minimally invasive surgery, ${ }^{1,3,5}$ including less postoperative pain, quicker recovery, and shorter hospital stay. ${ }^{2,6-8}$

Nevertheless, although laparoscopic techniques are being increasingly used in the management of various intra-abdominal conditions, there is conflicting evidence regarding the effect of laparoscopic surgery on postoperative systemic inflammatory response. Specifically, concern has been raised that increased intra-abdominal pressure during laparoscopy may promote bacteremia and systemic inflammation,, 9 while recent findings suggest that carbon dioxide pneumoperitoneum could have a protective effect against postoperative enhanced systemic inflammation, particularly after laparoscopic cholecystectomy. ${ }^{3,10,11}$

Immunity and inflammation after surgery are mediated by cytokines, such as tumour necrosis factor- $\alpha$ (TNF- $\alpha$ ), interleukin (IL)-1, and IL-6, which are activated as an early response to tissue injury. ${ }^{12-14}$ Specifically, IL-6 is the main cytokine responsible for inducing the systemic changes known as the acute phase response, which includes the production of acute phase proteins in the liver, such as C-reactive protein (CRP), and plays a major role in inflammation. ${ }^{14-17}$

Moreover, surgical stress response is characterized by increased secretion of pituitary hormones, decreased secretion or effects of anabolic hormones, and hypermetabolism. The overall metabolic effect of the tissue injury-induced endocrine and metabolic changes is increased catabolism, and those changes are thought to mediate the increased demand on the reserves and immune competence of patients post surgery. ${ }^{2,14,18}$ In particular, growth hormone (GH) is secreted by the anterior pituitary and its secretion increases in relation to the severity of tissue injury after surgery. ${ }^{14}$ Many GH actions are mediated by insulin-like growth factor-1 (IGF-1), which, in the context of its endocrine activity, is produced and secreted by the liver, skeletal muscle, and other tissues in response to stimulation by GH. ${ }^{19-21}$ Furthermore, it has been proposed that acute inflammation induces a GH-resistant state as part of a regulatory mechanism of the body to restrict growth and energy storage, in which the elevated GH secretion is not followed by increased circulating IGF-1 levels. ${ }^{22-24}$

Although the effect of surgical stress and/or inflammatory responses on endocrine function after laparoscopic surgery has been described in humans, ${ }^{2,13,25-27}$ studies designed to detect the relation between the response of the anabolic GH/IGF-1 axis and laparoscopic cholecystectomy in the context of an acute phase response are lacking. This prospective study aimed at determining whether there are acute phase changes in growth axis hormones in patients who underwent laparoscopic cholecystectomy.

\section{MATERIALS AND METHODS}

\section{Ethical approval}

All experimental procedures were in accordance with the ethical standards of the Ethics Committee of the Institutional Review Board of "Laiko" General Hospital, which approved the study, and with the Declaration of Helsinki. Written informed consent was provided by all volunteers participating in this study.

\section{Patients}

From September 2013 to May 2014, a hospitalbased prospective study was conducted in 29 consecutive patients ( 16 women, 13 men; age $58 \pm 8$ years). They had a history of uncomplicated symptomatic cholelithiasis and were referred to the authors' department for surgical treatment of their disease. The patients were scheduled for laparoscopic cholecystectomy and had not received any treatment for at least a week before they underwent the surgical excision of the gallbladder. In all patients, general anesthesia was induced with propofol or midazolam, while postoperative analgesia consisted of routine administration of fentanyl or paracetamol. The choice of anesthetics was determined by the attending anesthesiologists. Patients were released from hospital on the third postoperative day.

\section{Blood sampling and serum measurements}

Blood samples were collected between 8:00 and 9:00 am from each individual patient before the op- 
eration (during the patients' preoperative medical examination) and after the laparoscopic removal of the gallbladder (cholecystectomy), at 24 and $48 \mathrm{hrs}$. The time points of blood sampling were chosen to cover the period of acute phase response following laparoscopic surgery. The patients were at rest for at least $30 \mathrm{~min}$ prior to collection of $10 \mathrm{~mL}$ of blood obtained from an antecubital vein. Blood samples were allowed to clot at room temperature for $30 \mathrm{~min}$. Serum was collected following centrifugation at $2000 \mathrm{~g}$ at $4^{\circ} \mathrm{C}$ for $10 \mathrm{~min}$, stored frozen in $0.2 \mathrm{~mL}$ aliquots at $-80^{\circ} \mathrm{C}$, and thawed once only at the time of analysis. CRP was measured by latex-enhanced nephelometry (Dade Behring Nephelometer II Analyzer System, BNII, Siemens, Erlangen, Germany). Serum concentrations of IGF-1, insulin-like growth factor binding protein (IGFBP)-3, GH, and the acute phase protein IL-6 were determined by standard sandwich enzyme-linked immunosorbent assay (ELISA) using commercially available kits (IGF-1: Enzo Life Sciences, Michigan, USA; IGFBP-3 and GH: R\&D Systems Inc., Minneapolis, USA; IL-6: Biolegend Inc., San Diego, USA) according to the manufacturer's instructions. Briefly, 96-well microtiter plates (Costar) were coated with a monoclonal antibody directed against the analyte. Samples and standards were applied and the bound analyte was detected with horseradish peroxidase conjugated to a secondary polyclonal antibody directed against the analyte. Visualization of the presence of the peroxidase label was achieved with a tetramethylbenzidine (TMB) substrate. Colour formation was measured with a microplate reader (Versamax, Molecular Devices, Sunnyvale, CA, USA) at 450 or 540 $\mathrm{nm}$, and calculations were performed using SoftMax Pro software (Molecular Devices, Sunnyvale, CA, USA). All samples were analyzed simultaneously, in duplicate and the results averaged. According to the manufacturers, the minimal detection limits of the assays were $34.2 \mathrm{pg} \mathrm{mL}^{-1}, 50 \mathrm{pg} \mathrm{mL}^{-1}, 2.1 \mathrm{pg}$ $\mathrm{mL}^{-1}, 1.6 \mathrm{pg} \mathrm{mL}^{-1}$ for IGF-1, IGFBP-3, GH and IL-6, respectively. The intra- and inter-assay coefficients of variation (CV) were as follows: $3.6 \%-8.9 \%$ and $3.4 \%-10.9 \%$ for IGF- $1,2.3 \%-5.0 \%$ and $5.4 \%-8 \%$ for IGFBP-3, 2.4\%-4.1\% and $6.9 \%-9.4 \%$ for $\mathrm{GH}$, and $4.3 \%-11.3 \%$ and $4.5 \%-13 \%$ for IL-6.

\section{Statistical analysis}

A one-way analysis of variance (ANOVA) with repeated measures over time was employed to evaluate changes in all serum measurements (SPPS v. 21 statistical package; SPSS Inc., Chicago, IL, USA). Where significant $\mathrm{F}$ ratios were found for main effects ( $p<0.05$ ), the postoperative mean values were compared with the preoperative means (control) using Dunnett's post hoc tests. Relationships between variables were examined using Pearson's correlation coefficient (r). All data are presented as mean \pm SE. Statistically significant changes were considered at $\mathrm{p}<0.05$.

\section{RESULTS}

The coefficient $\mathrm{r}^{2}$ for standard curves of all the ELISA analyses was $0.994-1$. Analysis of the inflammation-related factor IL-6 in the blood revealed that the laparoscopic cholecystectomy resulted in a significant three-fold increase of circulating IL-6 levels on postoperative day 2 (48 $\mathrm{hrs}$ ) compared to the preoperative (PRE) levels (17.9 \pm 4.6 vs. $5.2 \pm 1.9$ $\mathrm{pg} / \mathrm{ml}$; F ratio: $3.142, \mathrm{p}=0.045$, Table 1). Similarly, there was a significant five-fold increase in the serum levels of the acute phase protein CRP on postoperative day 2 compared to the preoperative levels $(20.9 \pm 5.6$ vs. $3.87 \pm 0.28 \mathrm{mg} / \mathrm{L}$; F ratio: $4.965, \mathrm{p}=0.010$, Table 1). A significant two-fold increase was observed in the levels of GH on postoperative day 1 ( $24 \mathrm{hrs}$ ) before returning to the preoperative levels on day 2 (PRE levels: $520.6 \pm 141.2$ vs. $1100.9 \pm 216.1$ vs.

Table 1. Serum concentrations of the growth axis hormones GH, IGF-1, and IGFBP-3, and of the acute phase proteins IL-6 and CRP, preoperatively (PRE) and on days 1 and 2 post laparoscopic cholecystectomy. $\mathrm{P}$ values refer to comparisons with the preoperative concentration (mean $\pm \mathrm{SE}$ )

\begin{tabular}{lccc}
\hline & PRE & Day 1 & Day 2 \\
\hline $\begin{array}{l}\text { GH } \\
(\mathrm{pg} / \mathrm{ml})\end{array}$ & $520.6 \pm 141.2$ & $\begin{array}{c}1100.9 \pm 216.1 \\
(\mathbf{p}=\mathbf{0 . 0 3 4})\end{array}$ & $\begin{array}{c}505.6 \pm 142.8 \\
(\mathrm{p}=0.997)\end{array}$ \\
$\begin{array}{l}\mathrm{IGF}-1 \\
(\mathrm{ng} / \mathrm{ml})\end{array}$ & $130.9 \pm 12.3$ & $\begin{array}{c}110.6 \pm 13.2 \\
(\mathbf{p}=\mathbf{0 . 0 4 5})\end{array}$ & $\begin{array}{c}110.5 \pm 11.1 \\
(\mathbf{p}=\mathbf{0 . 0 4 4})\end{array}$ \\
$\mathrm{IGFBP}-3$ & $1.95 \pm 0.14$ & $1.96 \pm 0.13$ & $1.96 \pm 0.14$ \\
$(\mu \mathrm{g} / \mathrm{ml})$ & & $(\mathrm{p}=1.000)$ & $(\mathrm{p}=0.997)$ \\
$\mathrm{IL}-6$ & $5.2 \pm 1.9$ & $\begin{array}{c}11.9 \pm 3.0 \\
(\mathrm{p}=0.319)\end{array}$ & $\begin{array}{l}17.9 \pm 4.6 \\
(\mathbf{p}=\mathbf{0 . 0 3 1})\end{array}$ \\
$\mathrm{CRP} / \mathrm{ml})$ & & $10.76 \pm 2.56$ & $20.9 \pm 5.6$ \\
$(\mathrm{mg} / \mathrm{L})$ & $3.87 \pm 0.28$ & $(\mathrm{p}=0.368)$ & $(\mathbf{p}=\mathbf{0 . 0 0 5})$ \\
\hline
\end{tabular}


$505.6 \pm 142.8 \mathrm{pg} / \mathrm{ml}$; F ratio: $3.971, \mathrm{p}=0.022$, Table 1). Circulating IGF-1 levels were significantly decreased on both postoperative days (PRE levels: $130.9 \pm 12.3$ vs. $110.6 \pm 13.2$ vs. $110.5 \pm 11.1 \mathrm{ng} / \mathrm{ml}$; F ratio: 3.766 , $\mathrm{p}=0.031$, Table 1 ), while no changes were observed in serum levels of IGFBP-3 throughout the experimental period (PRE levels: $1.95 \pm 0.14$ vs. $1.96 \pm 0.13$ vs. $1.96 \pm 0.14 \mu \mathrm{g} / \mathrm{ml}$; F ratio: $0.002, \mathrm{p}=0.998$, Table 1). Correlation analyses showed significant associations between the circulating levels of the acute phase proteins and the growth axis hormones, as shown in Table $2(\mathrm{p}<0.05-0.001)$.

\section{DISCUSSION}

Several aspects of postoperative endocrine responses have been described after minimally invasive surgery; however, there is little information regarding the effect of laparoscopic cholecystectomy on the growth endocrine axis. In this prospective trial, we evaluated changes in circulating GH/IGF-1 axis proteins in patients who underwent laparoscopic cholecystectomy. The main finding of the study is that even after this minimally invasive surgery, acute phase responses of the growth endocrine axis are induced, as indicated by the postoperative changes in the circulating levels of IL-6, CRP, GH, and IGF-1.

Changes in circulating levels of IL-6 precede the increase in serum concentration of other acute phase proteins, such as CRP, that act as inflamma- tory mediators. ${ }^{14,15,28}$ The study of these two inflammation biomarkers, and particularly of IL-6, allows direct quantification of the acute phase inflammatory response, ${ }^{28}$ as IL-6 and IL-1 are major activators of the cell-mediated immune system response. IL-6 production (as well as that of CRP), which seems to be the most indicative of the severity of tissue injury, is normally moderate in a minimally invasive procedure such as laparoscopic surgery. ${ }^{13,14,29-34}$

In the present study, a gradual increase in the circulating levels of both IL-6 and CRP was observed on postoperative days 1 and 2, which became significant $48 \mathrm{hrs}$ after the laparoscopic removal of the gallbladder, while high positive correlations were also observed between the postoperative levels of these acute phase factors, indicating their similar responses following the laparoscopic surgery. Similarly, transient ${ }^{3,33}$ or sustained ${ }^{2,4,35,36}$ increases in IL-6 and CRP levels have previously been reported after laparoscopic cholecystectomy, indicating the induction of an acute phase inflammatory response following this minimally invasive surgery.

The inflammatory cytokine actions are mediated, at least partially, by indirect changes in the activity of growth promoting hormones such as GH and IGF-1. ${ }^{37}$ The stress response to surgery is comprised of a number of hormonal changes induced by neural activation of the hypothalamic-pituitary axis. The duration and magnitude of this response is proportional to the tissue

Table 2. Significant correlations revealed between the circulating levels of the growth axis hormones GH, IGF-1, and IGFBP-3, and the acute phase proteins IL-6 and CRP, preoperatively (PRE) and on days 1 and 2 post laparoscopic cholecystectomy

\begin{tabular}{|c|c|c|c|c|c|c|}
\hline & $\begin{array}{l}\text { CRP } \\
\text { PRE }\end{array}$ & $\begin{array}{l}\text { CRP } \\
\text { Day } 1\end{array}$ & $\begin{array}{l}\text { CRP } \\
\text { Day } 2\end{array}$ & $\begin{array}{l}\text { IL-6 } \\
\text { Day } 1\end{array}$ & $\begin{array}{l}\text { BP-3 } \\
\text { Day } 1\end{array}$ & $\begin{array}{l}\text { BP-3 } \\
\text { Day } 2\end{array}$ \\
\hline $\begin{array}{l}\text { GH } \\
\text { Day } 2\end{array}$ & & $\begin{array}{c}r=0.749 \\
(p<0.001)\end{array}$ & $\begin{array}{c}\mathrm{r}=0.803 \\
(\mathrm{p}<0.001)\end{array}$ & $\begin{array}{c}\mathrm{r}=0.444 \\
(\mathrm{p}=0.020)\end{array}$ & & \\
\hline $\begin{array}{l}\text { IGF-1 } \\
\text { PRE }\end{array}$ & $\begin{array}{l}r=-0.477 \\
(p=0.025)\end{array}$ & & & & & \\
\hline $\begin{array}{l}\text { IGF-1 } \\
\text { Day } 1\end{array}$ & & & & & $\begin{array}{c}\mathrm{r}=0.571 \\
(\mathrm{p}=0.001)\end{array}$ & \\
\hline $\begin{array}{l}\text { IGF-1 } \\
\text { Day } 2 \\
\text { BP-3 } \\
\text { Day } 2\end{array}$ & $\begin{array}{l}\mathrm{r}=-0.471 \\
(\mathrm{p}=0.027)\end{array}$ & $\begin{array}{c}\mathrm{r}=0.431 \\
(\mathrm{p}=0.040)\end{array}$ & $\begin{array}{c}\mathrm{r}=0.484 \\
(\mathrm{p}=0.012)\end{array}$ & $\begin{array}{c}r=0.395 \\
(\mathrm{p}=0.041)\end{array}$ & $\begin{array}{c}r=0.540 \\
(\mathrm{p}=0.002)\end{array}$ & $\begin{array}{c}\mathrm{r}=0.790 \\
(\mathrm{p}<0.001)\end{array}$ \\
\hline $\begin{array}{l}\text { IL-6 } \\
\text { Day } 1\end{array}$ & & $\begin{array}{c}\mathrm{r}=0.887 \\
(\mathrm{p}<0.001)\end{array}$ & $\begin{array}{c}\mathrm{r}=0.860 \\
(\mathrm{p}<0.001)\end{array}$ & & & \\
\hline
\end{tabular}


injury and has an overall catabolic effect on stored body fuels. ${ }^{14}$ More specifically, IGF-1 is implicated in a vast number of physiological functions related to tissue growth, development, and metabolism. ${ }^{20,38-40}$ Trauma and conventional surgery result in a state of acquired GH resistance, characterized by high GH levels, decreased anabolic response to $\mathrm{GH}$ administration, and reduced levels of its main effector, IGF-1. 14,22,41,42 It is thought that the acute reduction in circulating IGF-1 levels reflects suppression of the GH/IGF-1 axis in response to the acute stress of surgery. ${ }^{22,24,43}$

In this study, decreased levels of circulating IGF-1 were found on both postoperative days after laparoscopic cholecystectomy. This decrease was accompanied by a transient increase in GH levels on the first postoperative day, indicating possible growth hormone axis suppression similar to that described after conventional surgery. In addition, significant positive correlations were revealed between the postoperative response of acute phase proteins and $\mathrm{GH}$, as well as inverse correlations between CRP and IGF-1 pre- and postoperative levels. Overall, these relationships may reflect a regulatory effect of IL-6 and CRP on growth axis hormones compatible with a state of systemic inflammation and GH resistance. ${ }^{37,42}$ Moreover, the postoperative correlations found between acute phase proteins and IGFBP-3 may suggest a compensatory systemic response of IGFBP-3 to increase the diminished IGF-1 levels via acute inflammation. The influence of anesthesia could contribute to these stress-induced postoperative changes in GH/IGF-1 levels, ${ }^{44,45}$ although a persistent, lasting more than two days, and not transient increase in GH levels has been reported after major surgical trauma. ${ }^{44}$ To our knowledge, this is the first study showing concurrently the acute phase changes in $\mathrm{GH} /$ IGF-1 axis hormones after this minimally invasive cholecystectomy and expands on previous evidence that laparoscopic cholecystectomy can induce an acute endocrine stress response. ${ }^{7,13}$

Alterations in cytokines and endotoxin may decrease GH receptor availability in the liver, leading to reduced levels of circulating IGF-1, ${ }^{46-48}$ while the decreased levels of IGF-1 may result in increased GH secretion due to the lack of negative (inhibitory) feedback of IGF-1. ${ }^{24,41,49}$ Taking into consideration the acute inflammatory response observed in the present study, it can be speculated that the GH/IGF1 responses may represent cytokine-induced antianabolic or catabolic effects even after laparoscopic cholecystectomy. Furthermore, neuroendocrine stress response and inflammatory response, activated by afferent impulses from the site of tissue injury to the brain, ${ }^{14}$ occur following laparoscopic cholecystectomy. ${ }^{26,50}$ Central administration of IGF-1 can counteract the activity of pro-inflammatory cytokines produced in the brain; ${ }^{24,51,52}$ however, its decreased levels observed in this study are not likely to attenuate a neuro-inflammatory response.

Although it was previously postulated that circulating or locally produced IGF-1 mediates the growthpromoting actions of $\mathrm{GH},{ }^{39,53,54}$ it has since been established that GH and IGF-1 can also act independently of each other. ${ }^{55}$ Furthermore, investigation into IGF-1 and IGFBP-3 has been used for the evaluation of GH/ IGF-1 axis disorders. ${ }^{56}$ Biological actions of IGF-1 are modulated by a family of at least six IGFBPs, as they bind IGF-1 and increase its half-life in the circulation. ${ }^{57}$ Most of the circulating IGF-1 is protected from proteolytic degradation by forming a ternary complex with IGFBP-3 and the glycoprotein acid-labile subunit (ALS).$^{58}$ IGFBPs, and particularly IGFBP-3, can modulate, both in the circulation and the extracellular environment, the extent of IGF-dependent effects via the regulation of free IGF-1 concentration and its local bioavailability in the tissue. ${ }^{59,60}$

After major surgery there are complex and diverse changes in IGF-1 and IGFBPs. Thus, a larger proportion of circulating smaller fractions of the IGF-1/IGFBP-3 complex has been reported after major conventional surgery, possibly as a result of proteolytic modification of IGFBP-3 to increase the bioavailability of IGF-1. ${ }^{43,61-63}$ In the present study, similarly to previous findings reported after laparoscopic colectomy, ${ }^{34}$ we did not observe any significant changes in the serum levels of IGFBP-3 on the two consecutive postoperative days after laparoscopic cholecystectomy, suggesting that minimally invasive cholecystectomy does not affect the circulating levels of this growth hormone axis protein. Interestingly however, we demonstrated high correlations between IGFBP-3 and IGF-1 levels on both postoperative days, indicating a possible regulatory effect of IGFBP-3 on circulating IGF-1 postoperatively. 
In conclusion, concurrent investigation of the changes in GH/IGF-1 axis hormones after laparoscopic cholecystectomy revealed that this minimally invasive procedure induces acute phases responses in the growth endocrine axis. It remains to be confirmed whether these responses reflect possible cytokineinduced anti-anabolic or catabolic effects even after this minimally invasive surgery.

\section{REFERENCES}

1. Buunen M, Gholghesaei M, Veldkamp R, Meijer DW, Bonjer HJ, Bouvy ND, 2004 Stress response to laparoscopic surgery: a review. Surg Endosc 18: 1022-1028.

2. Veenhof AA, Vlug MS, van der Pas MH, et al, 2012 Surgical stress response and postoperative immune function after laparoscopy or open surgery with fast track or standard perioperative care: a randomized trial. Ann Surg 255: 216-221.

3. Sista F, Schietroma M, Santis GD, et al, 2013 Systemic inflammation and immune response after laparotomy vs laparoscopy in patients with acute cholecystitis, complicated by peritonitis. World J Gastrointest Surgr 5: 73-82.

4. Madureira FA, Manso JE, Madureira Filho D, Iglesias AC, 2014 Inflammation in laparoendoscopic single-site surgery versus laparoscopic cholecystectomy. Surg Innov 21: 263-268.

5. Jacobi CA, Ordemann J, Zieren HU, et al, 1998 Increased systemic inflammation after laparotomy vs laparoscopy in an animal model of peritonitis. Arch Surg 133: 258-262.

6. Karamanakos SN, Sdralis E, Panagiotopoulos S, Kehagias I, 2010 Laparoscopy in the emergency setting: a retrospective review of 540 patients with acute abdominal pain. Surg Laparosc Endosc Percutan Tech 20: 119-124.

7. Targarona EM, Pons MJ, Balague C, et al, 1996 Acute phase is the only significantly reduced component of the injury response after laparoscopic cholecystectomy. World J Surg 20: 528-534.

8. Hendolin HI, Paakonen ME, Alhava EM, Tarvainen R, Kemppinen T, Lahtinen P, 2000 Laparoscopic or open cholecystectomy: a prospective randomised trial to compare postoperative pain, pulmonary function, and stress response. Eur J Surg 166: 394-399.

9. Chatzimavroudis G, Pavlidis TE, Koutelidakis I, et al, $2009 \mathrm{CO}(2)$ pneumoperitoneum prolongs survival in an animal model of peritonitis compared to laparotomy. J Surg Res 152: 69-75.

10. Boo YJ, Kim WB, Kim J, et al, 2007 Systemic immune response after open versus laparoscopic cholecystectomy in acute cholecystitis: a prospective randomized study. Scand J Clin Lab Invest 67: 207-214.
11. Sorbello AA, Azevedo JL, Osaka JT, Damy S, Franca LM, Tolosa EC, 2010 Protective effect of carbon dioxide against bacterial peritonitis induced in rats. Surg Endosc 24: 1849-1853.

12. Reith HB, Kaman S, Mittelkotter O, Kilic Y, Kozuschek W, 1997 Cytokine activation in patients undergoing open or laparoscopic cholecystectomy. Int Surg 82: 389-393.

13. Bellon JM, Manzano L, Larrad A, Honduvilla GN, Bujan J, Alvarez-Mon M, 1998 Endocrine and immune response to injury after open and laparoscopic cholecystectomy. Int Surg 83: 24-27.

14. Desborough JP, 2000 The stress response to trauma and surgery. Br J Anaesth 85: 109-117.

15. Helmy SA, Wahby MA, El-Nawaway M, 1999 The effect of anaesthesia and surgery on plasma cytokine production. Anaesthesia 54: 733-738.

16. Philippou A, Maridaki M, Theos A, Koutsilieris M, 2012 Cytokines in muscle damage. Adv Clin Chem 58: 49-87.

17. Philippou A, Bogdanis G, Maridaki M, Halapas A, Sourla A, Koutsilieris M, 2009 Systemic cytokine response following exercise-induced muscle damage in humans. Clin Chem Lab Med 47: 777-782.

18. Kehlet H, 1997 Laparoscopic surgery--where do we stand? Nord Med 112: 280-282.

19. Ohlsson C, Mohan S, Sjogren K, et al, 2009 The role of liver-derived insulin-like growth factor-I. Endocr Rev 30: 494-535.

20. Barton ER, Park S, James JK, et al, 2012 Deletion of muscle GRP94 impairs both muscle and body growth by inhibiting local IGF production. FASEB J 26: 3691 3702.

21. Philippou A, Maridaki M, Pneumaticos S, Koutsilieris M, 2014 The complexity of the IGF1 gene splicing, posttranslational modification and bioactivity. Mol Med 20: 202-214.

22. Balcells J, Moreno A, Audi L, Roqueta J, Iglesias J, Carrascosa A, 2001 Growth hormone/insulin-like growth factors axis in children undergoing cardiac surgery. Crit Care Med 29: 1234-1238.

23. Mesotten D, Van den Berghe G, 2006 Changes within the GH/IGF-I/IGFBP axis in critical illness. Crit Care Clin 22: 17-28.

24. Cerejeira J, Batista P, Nogueira V, Vaz-Serra A, Mukaetova-Ladinska EB, 2013 The stress response to surgery and postoperative delirium: evidence of hypothalamicpituitary-adrenal axis hyperresponsiveness and decreased suppression of the GH/IGF-1 Axis. J Geriatr Psychiatry Neurol 26: 185-194.

25. Ortega AE, Peters JH, Incarbone R, et al, 1996 A prospective randomized comparison of the metabolic and stress hormonal responses of laparoscopic and open cholecystectomy. J Am Coll Surg 183: 249-256.

26. Karayiannakis AJ, Makri GG, Mantzioka A, Karousos D, Karatzas G, 1997 Systemic stress response after 
laparoscopic or open cholecystectomy: a randomized trial. Br J Surg 84: 467-471.

27. Batrinos ML, Panitsa-Faflia C, Koutsoumanis C, Vourlioti T, Koutsilieris M, 1999 Surgical stress induces a marked and sustained increase of adrenal androgen secretion in postmenopausal women. In Vivo 13: 147150 .

28. Ohzato H, Yoshizaki K, Nishimoto N, et al, 1992 Interleukin-6 as a new indicator of inflammatory status: detection of serum levels of interleukin- 6 and C-reactive protein after surgery. Surgery 111: 201-209.

29. Kloosterman T, von Blomberg BM, Borgstein P, Cuesta MA, Scheper RJ, Meijer S, 1994 Unimpaired immune functions after laparoscopic cholecystectomy. Surgery 115: 424-428.

30. Ueo H, Honda M, Adachi M, et al, 1994 Minimal increase in serum interleukin-6 levels during laparoscopic cholecystectomy. Am J Surg 168: 358-360.

31. Kristiansson M, Saraste L, Soop M, Sundqvist KG, Thorne A, 1999 Diminished interleukin-6 and C-reactive protein responses to laparoscopic versus open cholecystectomy. Acta Anaesthesiol Scand 43: 146-152.

32. Gupta A, Watson DI, 2001 Effect of laparoscopy on immune function. Br J Surg 88: 1296-1306.

33. Schietroma M, Carlei F, Franchi L, et al, 2004 A comparison of serum interleukin- 6 concentrations in patients treated by cholecystectomy via laparotomy or laparoscopy. Hepatogastroenterology 51: 1595-1599.

34. Kirman I, Poltaratskaia N, Cekic V, et al, 2004 Depletion of circulating insulin-like growth factor binding protein 3 after open surgery is associated with high interleukin-6 levels. Dis Colon Rectum 47: 911-918.

35. Harmon GD, Senagore AJ, Kilbride MJ, Warzynski MJ, 1994 Interleukin-6 response to laparoscopic and open colectomy. Dis Colon Rectum 37: 754-759.

36. Glaser F, Sannwald GA, Buhr HJ, et al, 1995 General stress response to conventional and laparoscopic cholecystectomy. Ann Surg 221: 372-380.

37. O’Connor JC, McCusker RH, Strle K, Johnson RW, Dantzer R, Kelley KW, 2008 Regulation of IGF-I function by proinflammatory cytokines: at the interface of immunology and endocrinology. Cell Immunol 252: 91-110.

38. Liu JL, Yakar S, LeRoith D, 2000 Mice deficient in liver production of insulin-like growth factor I display sexual dimorphism in growth hormone-stimulated postnatal growth. Endocrinology 141: 4436-4441.

39. Hayes VY, Urban RJ, Jiang J, Marcell TJ, Helgeson K, Mauras N, 2001 Recombinant human growth hormone and recombinant human insulin-like growth factor I diminish the catabolic effects of hypogonadism in man: metabolic and molecular effects. J Clin Endocrinol Metab 86: 2211-2219.

40. Stratikopoulos E, Szabolcs M, Dragatsis I, Klinakis A, Efstratiadis A, 2008 The hormonal action of IGF1 in postnatal mouse growth. Proc Natl Acad Sci U S A
105: 19378-19383.

41. Carroll PV, 1999 Protein metabolism and the use of growth hormone and insulin-like growth factor-I in the critically ill patient. Growth Horm IGF Res 9: 400-413.

42. Nakhjavani M, Esteghamati A, Hamidi S, et al, 2009 Changes in growth hormone and insulin-like growth factor-I levels in the acute stage after open heart surgery and at the time of discharge. Exp Clin Endocrinol Diabetes 117: 413-416.

43. Cotterill AM, Mendel P, Holly JM, et al, 1996 The differential regulation of the circulating levels of the insulin-like growth factors and their binding proteins (IGFBP) 1, 2 and 3 after elective abdominal surgery. Clin Endocrinol (Oxf) 44: 91-101.

44. Roth-Isigkeit A, Brechmann J, Dibbelt L, Sievers HH, Raasch W, Schmucker P, 1998 Persistent endocrine stress response in patients undergoing cardiac surgery. J Endocrinol Invest 21: 12-19.

45. Wallin MK, Sellden E, Eksborg S, Brismar K, 2007 Amino acid infusion during anesthesia attenuates the surgery induced decline in IGF-1 and diminishes the "diabetes of injury". Nutr Metab (Lond) 4: 2.

46. Wolf M, Bohm S, Brand M, Kreymann G, 1996 Proinflammatory cytokines interleukin 1 beta and tumor necrosis factor alpha inhibit growth hormone stimulation of insulin-like growth factor I synthesis and growth hormone receptor mRNA levels in cultured rat liver cells. Eur J Endocrinol 135: 729-737.

47. Defalque D, Brandt N, Ketelslegers JM, Thissen JP, 1999 GH insensitivity induced by endotoxin injection is associated with decreased liver GH receptors. Am J Physiol 276: E565-572.

48. Priego T, Granado M, Ibanez de Caceres I, Martin AI, Villanua MA, Lopez-Calderon A, 2003 Endotoxin at low doses stimulates pituitary $\mathrm{GH}$ whereas it decreases IGF-I and IGF-binding protein-3 in rats. J Endocrinol 179: 107-117.

49. Wilson K, Broadhurst C, Diver M, Jackson M, Mottram P, 2005 Plasma insulin growth factor-1 and incident delirium in older people. Int J Geriatr Psychiatry 20: 154-159.

50. Schauer PR, Sirinek KR, 1995 The laparoscopic approach reduces the endocrine response to elective cholecystectomy. Am Surg 61: 106-111.

51. Bluthe RM, Kelley KW, Dantzer R, 2006 Effects of insulin-like growth factor-I on cytokine-induced sickness behavior in mice. Brain Behav Immun 20: 57-63.

52. Park SE, Dantzer R, Kelley KW, McCusker RH, 2011 Central administration of insulin-like growth factor-I decreases depressive-like behavior and brain cytokine expression in mice. J Neuroinflammation 8: 12.

53. Bjarnason R, Wickelgren R, Hermansson M, Hammarqvist F, Carlsson B, Carlsson LM, 1998 Growth hormone treatment prevents the decrease in insulin-like growth factor I gene expression in patients undergoing abdominal surgery. J Clin Endocrinol Metab 83: 
1566-1572.

54. Brill KT, Weltman AL, Gentili A, et al, 2002 Single and combined effects of growth hormone and testosterone administration on measures of body composition, physical performance, mood, sexual function, bone turnover, and muscle gene expression in healthy older men. J Clin Endocrinol Metab 87: 5649-5657.

55. Lupu F, Terwilliger JD, Lee K, Segre GV, Efstratiadis A, 2001 Roles of growth hormone and insulin-like growth factor 1 in mouse postnatal growth. Dev Biol 229: 141-162.

56. Bajpai A, Menon PS, 2006 Insulin like growth factors axis and growth disorders. Indian J Pediatr 73: 67-71.

57. Baxter RC, 2000 Insulin-like growth factor (IGF)binding proteins: interactions with IGFs and intrinsic bioactivities. Am J Physiol Endocrinol Metab 278: E967-976.

58. Baxter RC, Martin JL, Beniac VA, 1989 High molecular weight insulin-like growth factor binding protein complex. Purification and properties of the acid-labile subunit from human serum. J Biol Chem 264: 1184311848 .
59. Firth SM, Baxter RC, 2002 Cellular actions of the insulin-like growth factor binding proteins. Endocr Rev 23: 824-854.

60. Martin RM, Holly JM, Davey Smith G, Gunnell D, 2006 Associations of adiposity from childhood into adulthood with insulin resistance and the insulin-like growth factor system: 65-year follow-up of the Boyd Orr Cohort. J Clin Endocrinol Metab 91: 3287-3295.

61. Belizon A, Kirman I, Balik E, Karten M, Jain S, Whelan RL, 2007 Major surgical trauma induces proteolysis of insulin-like growth factor binding protein-3 in transgenic mice and is associated with a rapid increase in circulating levels of matrix metalloproteinase-9. Surg Endosc 21: 653-658.

62. Davenport ML, Isley WL, Pucilowska JB, et al, 1992 Insulin-like growth factor-binding protein-3 proteolysis is induced after elective surgery. J Clin Endocrinol Metab 75: 590-595.

63. Cwyfan Hughes SC, Cotterill AM, Molloy AR, et al, 1992 The induction of specific proteases for insulinlike growth factor-binding proteins following major heart surgery. J Endocrinol 135: 135-145. 